\title{
NEOLIBERALISM, CONSUMERISM, AND ENGLISH LANGUAGE TEACHING: A DISCOURSE ANALYSIS OF AN ENGLISH TEXTBOOK OF JUNIOR HIGH SCHOOL PEKANBARU
}

\author{
Melgis Dilkawaty Pratama \\ State Islamic University of Sultan Syarif Kasim Riau, Indonesia \\ melgis.dilkawaty.pratama@uin-suska.ac.id
}

\begin{abstract}
This study investigates the ideologies underlie in the English textbook of Junior High School in Pekanbaru. Those ideologies act as intended curriculum of English language teaching.However, some ideologies are contrary to the intended curriculum stated. Consequently, the English language teaching will bring wrong message to the students' mindset. The design of this study is discourse analysis which emphasizes on linguistic and socioeconomic views. This study revealed that the English textbook used neoliberalism and consumerism as the ideologies which is contradictive to the intended curriculum stated. Therefore, the use of this English textbook needs the comprehensive guidance of teachers in interpreting and explaining the content to the students.
\end{abstract}

Keywords: intended curriculum, implemented curriculum, ideology, neoliberalism, consumptive culture.

\section{Introduction}

Textbook is one of important media in teaching either for teachers or students. In textbook, the materials are arranged based on the curriculum. It is a combination between "intended curriculum" and "implemented curriculum". The "intended curriculum" means that the textbook is designed based on the standard competence, basic competence, and indicators that students have to achieve. The "implemented curriculum" means that the activities created based on textbook are arranged based on teacher's instruction. It can be in the form of exercise, homework, project, individual, pair, group, etc. What teachers should bear in mind that "implemented curriculum" of textbook is the results of interpretation of "intended curriculum". It means that "intended curriculum plays predominant role in the textbook. While "intended curriculum" is a complete package of students' experiences. In other words, what kind of experiences students should have are determined by the "intended curriculum" in the textbook.

"Intended curriculum" in the
textbook raises crucial multiple
interpretations. It occurs because
"intended curriculum" are colored by
the ideologies that the country holds
either politics or society. Ideologies lie
in the "intended curriculum" are also
transformed in the textbook either in the
surface or deep level. It can be placed
either in the organization of textbooks


or in the content of textbook. What teacher should carefully consider is the content of textbook because it is commonly used as the material discussion in learning process. If the ideologies lie in the material of textbook are contrary to the ideology of society or beliefs of people, it endangers the way students' think. The patterns of students' thinking are determined by the ideologies that they learn or familiar with. Later, they will do and behave based the ideologies that they have acquired. If the students' learn wrong or dangerous ideology, they will endanger the next generation-their future. Thus, selecting and analyzing the content of textbook that teacher will use are very important. Therefore, this paper tries to expose an analysis of a material chosen from English textbook in order to investigate the ideologies lie in the
English textbook, how they are legitimized, and its effect to students.

\section{Literature Review}

Textbook is a most important feature of the English language teaching because of its close relation to the classroom instruction. Textbook identifies the topics and order them in a way students should explore them. Textbook also attempts to specify how classroom lessons can be structured with suitable exercises and activities. Hence, textbooks are designed for the purpose to help teachers to organize their teaching.

Textbook, related to curriculum, is regarded as the potentially implemented curriculum, the link between aims and reality (Schmidt, et.al, 1997; Valverde, et.al, 2002).

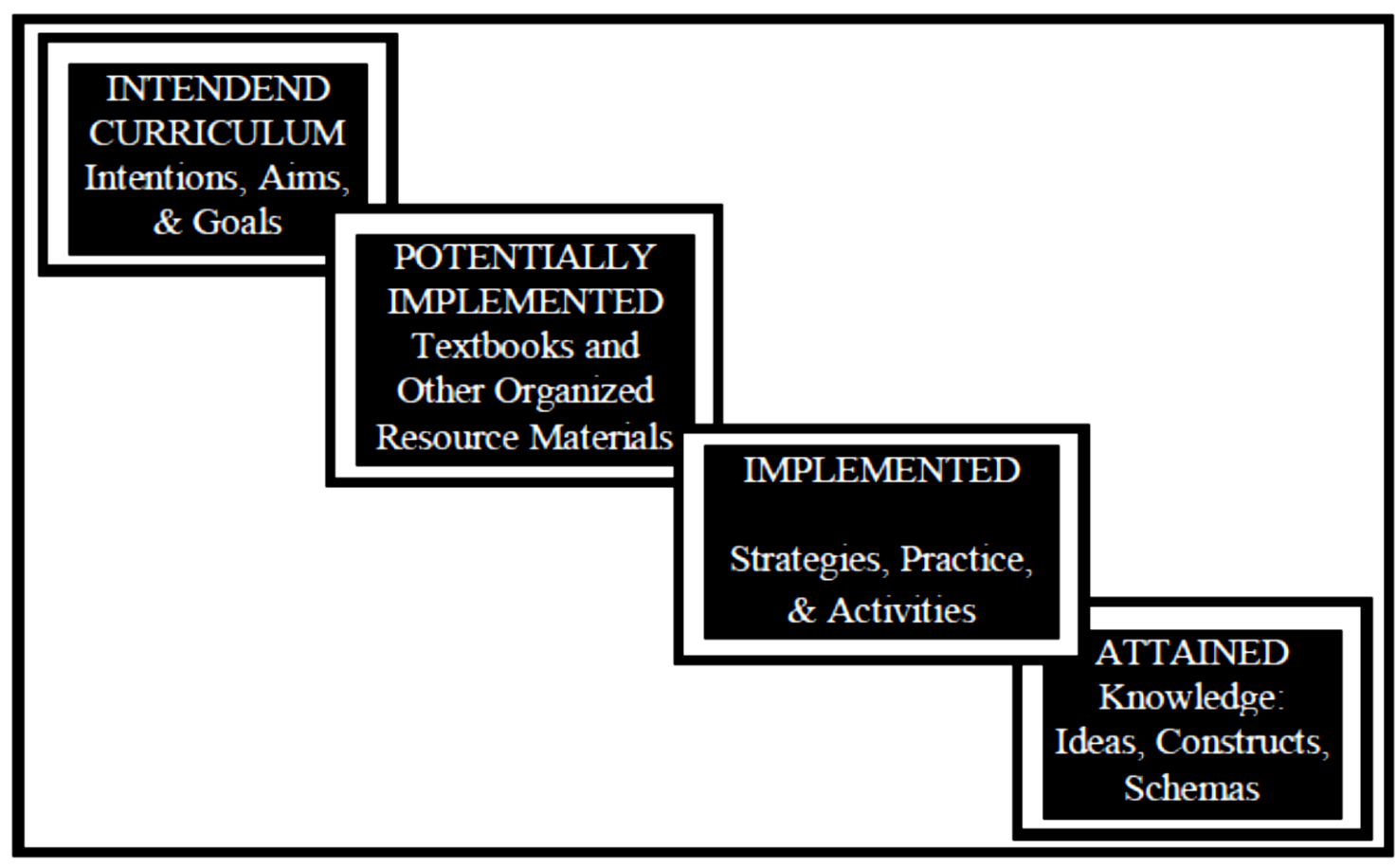

Figure 1: Textbooks and the tripartite model (Valverde et al., 2002, p.13)

In the figure 1 , the intended curriculum is at the educational system level. The intended curriculum is related to educational planning. Intention, aims, and goals at the level of the teacher and the classroom activity are considered as the implemented curriculum. The potentially implemented curriculum 
(textbooks and other resource materials) is regarded as a link between these two levels. The attained curriculum is on the student level. The result what takes place in classrooms at the level of student outcomes is therefore considered as the attained curriculum (Robitaille, et.al, 1997).

In textbook studies, only few consider that political and cultural roles that text may play in many aspects, this concept suggests that previous studies of textbooks assume texts to be "a delivery system of facts" as opposed to the "the results of political, economic, and cultural activities. Paggeler (1985) maintained that political influence in textbook is not limited to social science and may occur in subjects throughout to be apolitical; he argued that both textbook authors and educators are insufficiently aware of this influence. According to Crawford (2003, p. 5) textbooks:"....are a reflection of the history, knowledge and values considered important by powerful groups in society.'In 1991, Apple (p.46) noted that dearth of empirical studies that examine the economical social relations influenced in the production of cultural products such as textbook.

\section{Methods}

The design of this study is discourse analysis. The analyzed text is selected from the English textbook for ninth grade of Junior High School 23 Pekanbaru.The points of view used to analyze this textbook are linguistics and socioeconomic disciplines in which it tries to explore the value implemented in this textbook.

\section{Findings and Discussion}

Based on the data analysis, in this textbook, there are two ideologies identified: Consumptive culture and Neoliberalism.

1) Consumptive Culture (Consumerism)

There are many definitions of consumptive culture (consumerism) promoted by the expert. (1) "Consumerism" is the concept that consumers should be informed decision makers in the marketplace. (2) "Consumerism" is the concept that the marketplace itself is responsible for ensuring economic justice and fairness in society. While those definitions were being established, other people began using the term "consumerism" to mean "high levels of consumption". Thus, the word consumptive culture (consumerism) is commonly defined as the selfish and frivolous collecting of products or economic materialism.

The ideology of consumerism is widely spread out in many aspects of human life including education. In education, consumerism is not conveyed explicitly because controversy covers around this ideology. Some people believe that do lots activities of consumption does not describe any tolerance for unlucky people. While others believe, do that activities can legitimate your social status which reflects the hard efforts that you have done. Therefore, educators believe that consumerism should be presented in the teaching and learning process, including textbook. However, many educators still find that this ideology lies in the textbook. Similarly, Taki in Baleghizadeh and JannahMotahed (2010: 5) found that internationallydistributed textbook tend to represent a particular discourse type, i.e. the discourse of western economy and consumerism. The concept exposed 
by Taki can be found in the text, as follows:

"So far, we have shopped a lot. I bought some T-shirts and hundreds of wooden accessories. My mum bought a beautiful statue and my dad bought a large painting! The painting is not only beautiful but also very expensive."

The word "a lot" is used to express uncountable things. Then, "hundreds" is used as the entity of "wooden accessories". Those words indicate that the author tries to show extra-wealth that Astuti and her family have. The consumption of products like "some T-shirts", "hundreds of wooden accessories are unbeneficial because it is just considered as souvenirs, not for basic daily needs.

\section{2) Neoliberalism}

Neoliberalism is a term commonly defined as a political philosophy whose advocates support economic liberalizations, free trade and open markets, privatization, deregulation, and enhancing the role of the private sector in modern society. As Paul Treanor (2014) explains:

As you would expect from a complete philosophy, neoliberalism has answers to stereotypical philosophical questions such as "Why are we here" and "What should I do?". We are here for the market, and you should compete. Neo-liberals tend to believe that humans exist for the market, and not the other way around: certainly in the sense that it is good to participate in the market, and that those who do not participate have failed in some way. In personal ethics, the general neoliberal vision is that every human being is an entrepreneur managing their own life, and should act as such. Moral philosophers call this is a virtue ethic, where human beings compare their actions to the way an ideal type would act - in this case the ideal entrepreneur. Individuals who choose their friends, hobbies, sports, and partners, to maximise their status with future employers, are ethically neoliberal. This attitude not unusual among ambitious students - is unknown in any preexisting moral philosophy, and is absent from early liberalism. Such social actions are not necessarily monetarised, but they represent an extension of the market principle into non-economic area of life again typical for neoliberalism.

In addition, according to Giasehi in Baleghizadeh and JannahMotahed (2010: 4), images (their status) have become an integral component of presentation of language as well as culture and that students may find it difficult or even impossible to challenge the hidden positioning in the materials that it seems opportune to make it clear to ESL teachers how ideologies are being packaged and presented to them.

For example,

"My parents and I are in Bali now. We are staying in Nusa Dua Beach Hotel. Our room is big and cozy. It has a beach view!"

These sentences indicate that Astuti and her family tries on how to develop their hobbies or regular activities that can maximize their status in which it will affect their business relationship.

Even the reader of the letter is Astuti, but actually the real readers are 
students at ninth grade of Junior High School. So, both ideologies give effects to students either positive or negative. However, based on the explanation above, consumptive culture (consumerism) and neoliberalism are contradictory to our ideology (pancasila), and our society beliefs which promote cooperation and collaboration, meanwhile neoliberalism promotes individualism and competition. It tends to carry negative sides to students as illustrated at the figure 1 .

Neoliberalism and consumptive culture $($ consumerism) $\Rightarrow>$ teenager $\Rightarrow$ social class and social justice $=>$ individualism and competition $=>$ legitimation of white people power (rich people)

\section{Figure 1: Neoliberalism and consumerism for students}

Effects of neoliberalism for students are stated (Choper, 2008: 2) as follows:

a) incrimination and a breakdown in social solidarity;

b) the ability of the state to socially construct a crisis ${ }^{\text {ee }}$ of failing

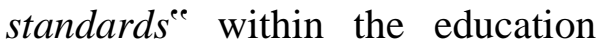
system (and subsequently retain legitimacy by appearing to take action to address these failing standards);

c) state interventions in education in the interest of powerful corporations (presented in the language of fairness and equity). "Presented the language fairness and equity",in this ideology, establishing fairness and equity is symbolized by the stability of social-economics status of people, and it tends to give good things for rich people who can establish it.

\section{Conclusion}

Textbook is a combination between "intended curriculum" and "implemented curriculum". "Intended curriculum" is lied on ideologies that the country or society holds. The ideologies can give positive and negative side to the teacher and students through textbook. Therefore, selecting the content of textbook becomes crucial things because if teachers are not aware to the ideologies lie in the textbook, probably it can give effects for students' pattern of thinking and their behavior. Furthermore, the analysis of content of textbook is much needed.

Based on the analysis conducted to the English textbook for ninth grade of Junior High School 23 Pekanbaru, the research question: "What ideologies underlay these themes and how are they legitimized?". The ideologies lied in this textbook are consumptive culture (consumerism) and neoliberalism. Both ideologies might give effect to students' way in thinking and behave particularly related to social class and social justice. Both ideologies promote individualism and competition in which it legitimate white power people (rich people).

Textbook plays important and indispensable media in teaching, particularly in performing language instruction, because in textbook, the contents organize already the exercises, tasks, and activities for students. Therefore, teachers should be carefully chosen which textbook should be learned by the students, because the effects of ideologies contained in the textbook seems more abstract, invisible, and influence students' mindset, then both teacher and students are hardly to detect it. Therefore, teachers are 
suggested to have regular meeting once a month or at least at the beginning of semester or at MGMP to discuss about which materials should be included as teaching materials from textbook or which one is not appropriate. Thus, selection of textbook is not only personal preferences of teacher, but also highly consideration from other teachers, either at first, second, or third level. However, of course other teachers are not suggested to involve deeply, but what teacher needs it other insights or points of view about the textbook, and it is expected that there is sustainability from material thought from the teacher at low lever to teacher at higher level.

\section{References}

Charlie Choper. (2008). "Review Essay: Neoliberalism, Education, and Strategies of Resistance". Unpublished.

Giasehi in Baleghizadeh and Jannah Motahed. (2010). " An Analysis of the Ideological Content of Internationally-Developed British and America ELT Textbook". The Journal of Teaching Language Skills (JTLS). Vol. 2 No. 2, Summer 2010.

Robitaille, D.F., et.al. (1993). Curriculum Frameworks for Mathematics and Science. (Vol. TIMSS Monograph No. 1). Vancouver: Pacific Educational Press.

Schmidt, W.H., et.al. (1997). Many Visions, Many Aims: A CrossNational Investigation of
Curricular Intentions in School Mathematics. (Vol. 1). Dordrecht: Kluwer.

Swagler, Roger (1997). "Modern Consumerism". In Brobeck, Stephen. Encyclopedia of the Consumer Movement. Santa Barbara, Calif.: ABC-Clio. pp. 172-173. ISBN 0874369878., which is based on Swagler, R. (1994). "Evolution and Applications of the Term Consumerism: Theme and Variations". Journal of Consumer Affairs28 (2): 347-360. doi:10.1111/j.17456606.1994.tb00856.x.

Takiin Baleghizadeh and Jannah Motahed.(2010). " An Analysis of the Ideological Content of Internationally-Developed British and America ELT Textbook". The Journal of Teaching Language Skills (JTLS). Vol. 2 No. 2, Summer 2010.

Treanor, Paul. (2014)."Neoliberalism: Origins, Theory, Definition". (Retrieved on 10 February 2014), http://web.inter.nl.net/users/Paul. Treanor/neoliberalism.html.

Valverde, G.A., et.al. (2002). According to the Book.Using TIMSS to Investigate the Translation of Policy into Practice through the World of Textbooks.Dordrecht: Kluwer Academic Publishers.

Zaida, Nur. (2013). Practice Your English Competence: for SMP/MTS Class IX. Jakarta: Erlangga. 